\title{
The USGS Role in TMDL Assessments
}

More than 218 million Americans live within 10 miles of a river, lake, or estuary that is considered impaired because it cannot fully support its aquatic biological communities or other designated uses or conform to fishable/ swimmable water-quality standards set by the States, Territories, or authorized Tribes. According to the U.S. Environmental Protection Agency (USEPA), there are more than 20,000 impaired water bodies (fig. 1). Excess sediments (clean sediment), nutrients (nitrogen and phosphorus), and pathogenic microorganisms are the leading causes of these impairments (USEPA, 2000).

"TMDL" stands for Total

Maximum Daily Load, and refers to the total quantity (or load) of a pollutant that a stream can carry and still conform to designated uses and fishable/swimmable water quality. TMDL also refers to a regulatory process that States, Territories, and authorized Tribes use to determine allowable pollutant concentrations in streams. The steps to restore water quality through the TMDL process are listed in table 1.

To address TMDL issues, waterresources managers and the regulatory community need to have adequate, reliable data concerning the processes occurring in a given water body. The U.S. Geological Survey (USGS) can assist parties responsible for implementing the TMDL process by providing (1) evaluation or interpretation of existing data, (2) monitoring and assessment of water bodies, (3) development of new approaches and tools, and (4) information sharing and technology transfer (table 1).

\section{THE USGS ROLE IN TMDL ASSESSMENTS}

The following sections describe the resources and tools that the USGS can provide to assist in the TMDL process. Examples from USGS studies are cited to illustrate how the resources and tools have been applied.

\section{Evaluation and Analysis of Existing Data}

The USGS has national databases of earth-science information that can be used for TMDL development (table 1). Long-term networks, state cooperative networks, and issue-specific networks provide consistent, quality-assured data at local, regional, and national scales. Water-quality, sediment, aquatic, ecological, geologic, and atmospheric

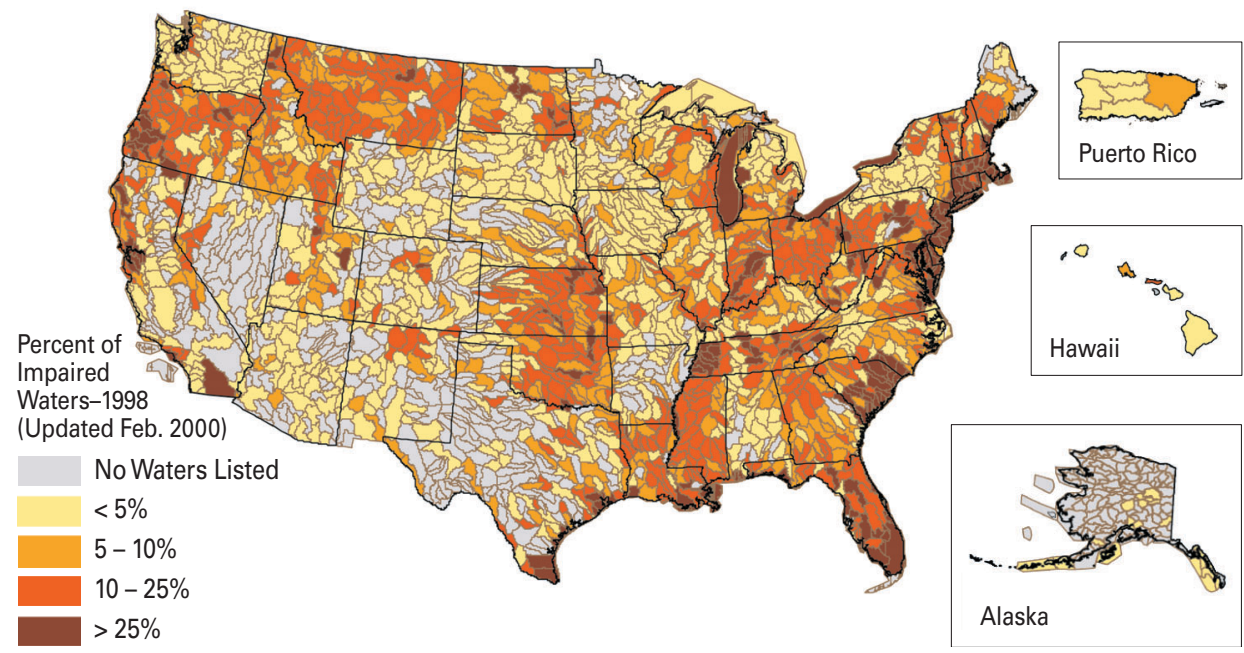

Figure 1. Map of watersheds containing impaired water bodies from the U.S. Environmental Protection Agency's 1998 list of impaired waters (USEPA, 2000). 
Table 1. The USGS can assist States, Territories, and authorizedTribes with the tasks that are part of the TMDL process.

\begin{tabular}{|c|c|c|c|c|}
\hline \multirow[b]{2}{*}{$\begin{array}{l}\text { Steps to restore water quality } \\
\text { through TMDL assessments }\end{array}$} & \multicolumn{4}{|c|}{ USGS Contributions to TMDL Assessments } \\
\hline & $\begin{array}{l}\text { Evaluation } \\
\text { of existing } \\
\text { data }\end{array}$ & $\begin{array}{l}\text { Monitoring } \\
\text { and } \\
\text { assessment }\end{array}$ & $\begin{array}{l}\text { Development } \\
\text { of new } \\
\text { approaches } \\
\text { and tools }\end{array}$ & $\begin{array}{l}\text { Information } \\
\text { sharing and } \\
\text { technology } \\
\text { transfer }\end{array}$ \\
\hline Identify impaired waters and determine pollutants & O & O & & O \\
\hline Prioritize water bodies for TMDL development & 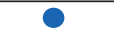 & O & & O \\
\hline Determine current loads of pollutants in streams & O & O & & O \\
\hline $\begin{array}{l}\text { Calculate maximum load that a water body can carry and } \\
\text { remain unimpaired (TMDL) }\end{array}$ & - & ○ & - & O \\
\hline Determine the necessary load reductions to meet the TMDL & & O & O & O \\
\hline $\begin{array}{l}\text { Identify sources of pollutants and relative contributions from } \\
\text { point- and nonpoint sources }\end{array}$ & - & O & O & - \\
\hline $\begin{array}{l}\text { Evaluate the effectiveness of alternative plans to achieve the } \\
\text { TMDL and restore water-body designated uses }\end{array}$ & & & - & - \\
\hline $\begin{array}{l}\text { Monitor the water body during and after implementation of } \\
\text { the plan to determine if TMDL levels are met and maintained }\end{array}$ & & 0 & - & 0 \\
\hline
\end{tabular}

Water-quality and streamflow data collected by the USGS as part of its national programs such as NAWQA (National Water-Quality Assessment), NASQAN (National Stream Quality Accounting Network), and NSIP (National Streamflow Information Program), and data from local studies reside in the National Water Information System (NWIS) database of the USGS. This database is now accessible through the Internet as NWISWeb (see web sites listed on p. 4). A broad range of data types at a variety of scales covering various time periods are available to water managers at NWISWeb. These data can be used to identify impaired waters, determine pollutants and pollutant loads, and prioritize water bodies for TMDL development.

As an example, Tennessee's waterquality regulatory agencies listed overenrichment of nutrients as the cause of impairment of 37 stream segments and 2 lakes within the lower Tennessee River Basin. Each water body listed is required to have a TMDL developed as part of the process to reduce nutrient concentrations. As part of a NAWQA assessment in this basin, nutrient inputs from nonpoint and point sources were determined for the lower Tennessee and 11 tributary basins (fig. 2). These data are used now by resource managers and policy makers for nutrient management (Woodside and Hoos, 2001).

The nationwide streamflow-gaging network operated by the USGS in cooperation with State agencies and other cooperators provides data that can be used to support TMDL studies. As an example, streamflow data from the cooperative USGS-New Jersey Department of Environmental Protection (NJDEP) stream-gaging pollutants, thereby saving thousands of dollars in analytical costs. Tennessee River Basin and tributary basins.

\section{Monitoring and Assessment}

The USGS routinely measures streamflow nationwide. In rivers, lakes, and estuaries nationwide, USGS also measures concentrations of constituents such as suspended sediment, nutrients, bacteria, trace metals, toxic organic compounds, and dissolved oxygen. These data are valuable for calculation of the current load of each constituent of concern when developing a TMDL (table 1) and to establish a baseline for trends. Because the load is the product of the flow and constituent concentration, accurate measurements of both are essential. These data can be used to determine the natural variability of flow and constituent concentration within the stream and critical periods during which concentrations of pollutants may vary based on seasonal or daily variations in flow, water chemistry, point-source discharge, or other variables.

Flow-weighted water-quality sampling is a standard USGS sampling procedure and, under most flow conditions, results in a more accurate representation of the actual constituent concentration in the stream than a grab sample. Because pollutant concentrations can vary with stream depth, channel morphology,

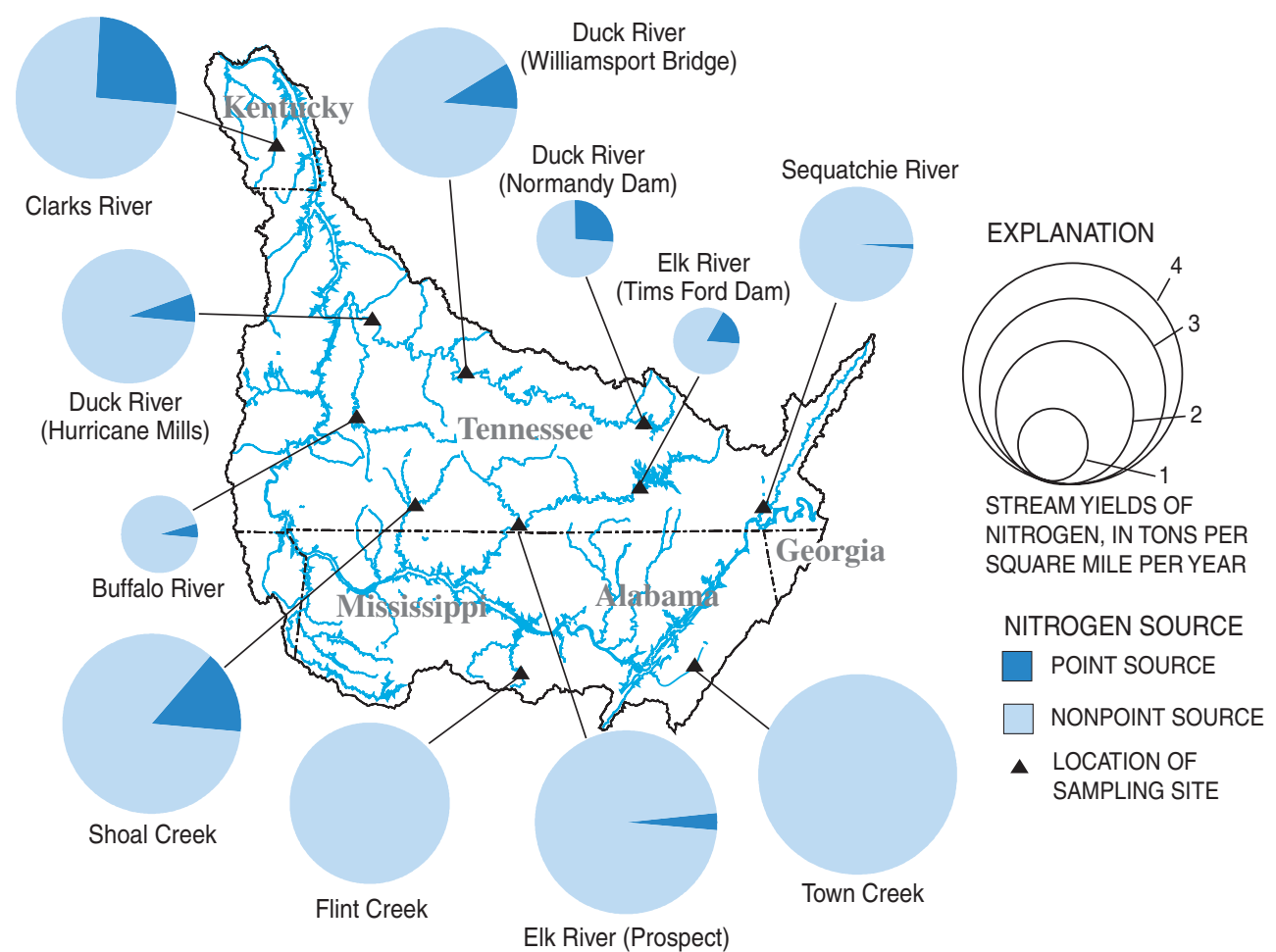

Figure 2. Estimated total nitrogen and the proportions of inputs from wastewater, atmospheric deposition, and agricultural inputs in the lower 


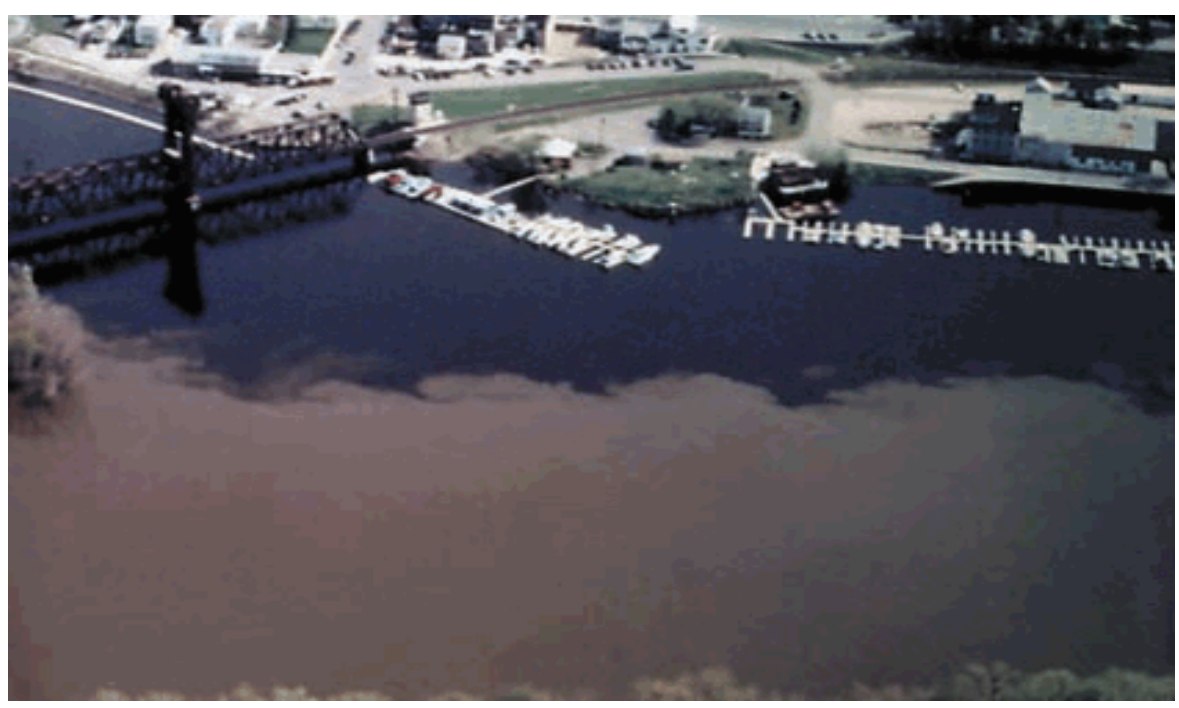

Figure 3. Sediment concentration variations below the confluence of the Mississippi and St. Croix Rivers during the spring snowmelt of 1994.

and other factors (fig. 3), a flow-weighted sample is collected by sampling along vertical profiles at several locations across the width of the stream channel. The result is a water-quality sample that integrates the full range of concentrations of a given constituent across a stream channel. This type of sample accurately reflects the load carried by the natural system.

Working in a variety of hydrologic settings across the country, the USGS has developed expertise needed to design networks, determine sampling frequency and sampling methods, and to interpret data. Understanding the hydrologic system and how chemical constituents are transported under varying flow conditions is important in evaluating how accurately a calculated load represents the actual load of a constituent. Interpretations provided by the USGS assist water-resource managers in developing TMDLs.

A TMDL implementation may include changes in land management, construction practices, permit limits, or planting buffers. After TMDL implementation, continued monitoring to calculate loads and trends is necessary to assess the effects that the TMDL has on the water body. Changes measured must be evaluated to determine whether they result from the TDML implementation or natural variation in the stream. Interpretation of follow-up monitoring can determine if the TMDL-defined loading goals are achieved and if they are meeting the goal of fishable and swimmable waters. concern that cannot be measured continuously. Relations have been developed to estimate fecal coliform bacteria from continuous turbidity measurements on the Little Arkansas River (fig. 4) to estimate loads and help define the accuracy of the data used for calculating TMDLs. These nearly real-time data may also be useful for considering human whole-body contact and recreation criteria, for adjusting water-treatment strategies, and for preventing adverse effects on aquatic life.

\section{Development of New Approaches and Tools}

The USGS can develop watershedspecific tools to assist resource managers in identification of the primary sources of pollutants and their relative contributions and in evaluation of the effectiveness of alternative TMDL plans. Laboratory procedures pioneered by USGS researchers can detect low-level concentrations of pollutants and identify emerging contaminants. New equipment for environmental monitoring is developed and tested by the USGS. These new procedures and tools may play an important role in establishing future TMDLs. In addition, sampling protocols are updated by the USGS to incorporate the latest advances in fieldsampling methods, resulting in consistent data collection across the country and over time. Sampling protocols are provided and frequently updated in publications such as the National Field Manual for the Collection of Water-Quality Data (U.S. Geological Survey, 1997-present).

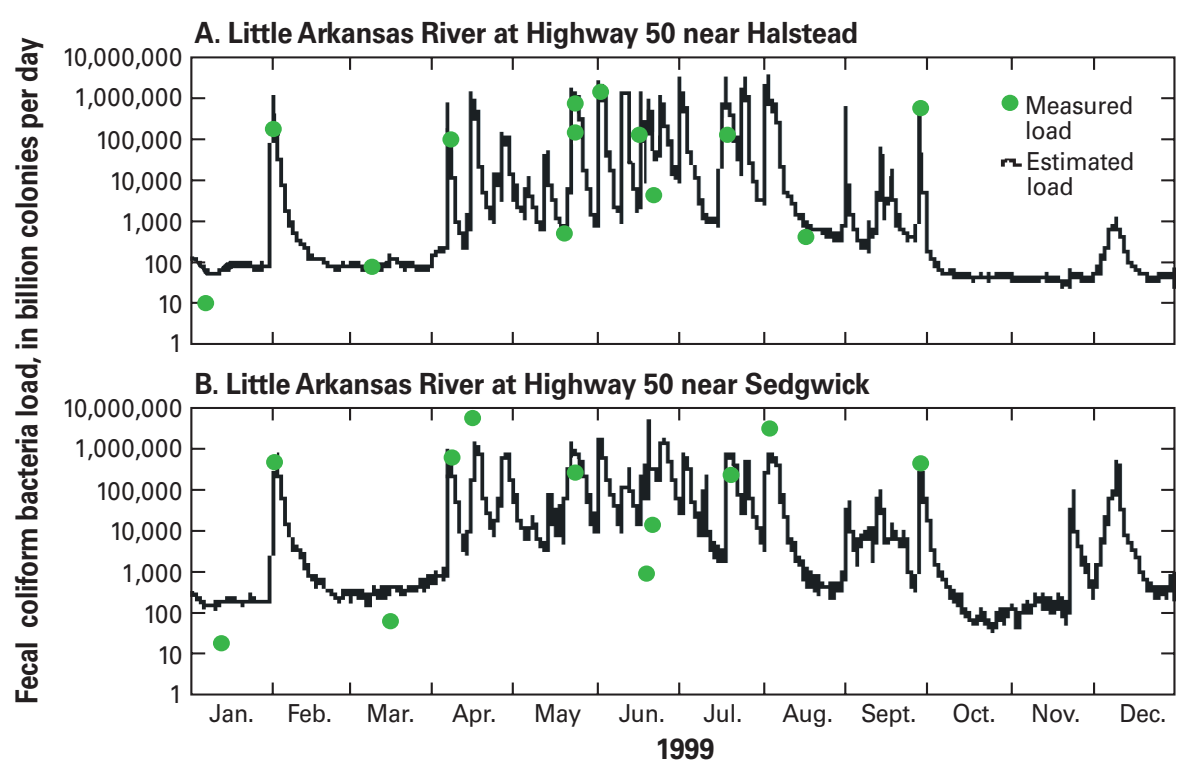

Figure 4. Comparison of measured loads of fecal coliform bacteria with estimated loads determined from turbidity at two sites on the Little Arkansas River, Kansas. 

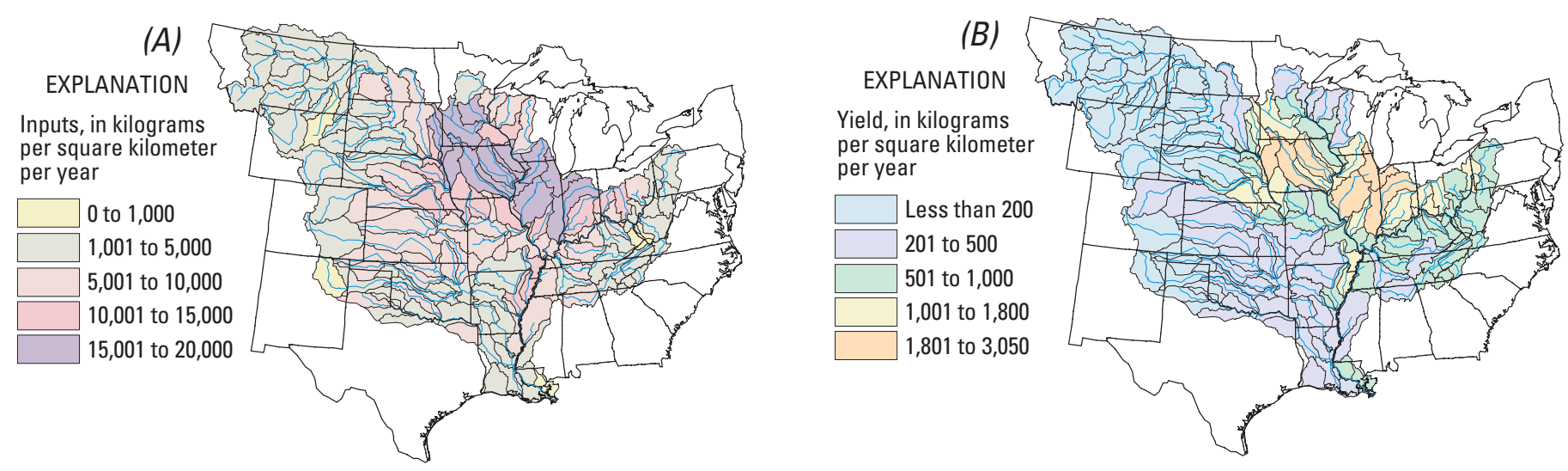

Figure 5. (A) Nitrogen inputs during 1992 and (B) average annual nitrogen yields of streams for 1980-96 (Modified from Goolsby and Battaglin, 2000).

An example of a new tool developed by the USGS is the SPARROW (Spatially Referenced Regression on Watersheds) (Smith and others, 1997) model, which is used for interpretation of regional waterquality data. This surface-water-quality modeling technique relates in-stream waterquality measurements to spatially referenced characteristics of watersheds, including pollutant sources and land-surface characteristics that affect pollutant delivery. Although SPARROW has only been used to simulate nitrogen and phosphorus loading, new versions are being developed to simulate loading of suspended sediments and fecal coliform bacteria. "The SPARROW model can be used for TMDL assessments in (1) large rivers where other types of modeling are difficult or expensive, and (2) coastal areas. Simulations with SPARROW also provide a good "first look" at major source contribution areas (fig. 5). As this Fact Sheet went to press, an adaptation of SPARROW for application at subregional scales was being tested.

The USGS is a leader in the development of techniques and methods to assess contaminants on regional and national scales. As part of the USGS Toxic Substances Hydrology Program, a national reconnaissance study is in progress to provide baseline information on the occurrence of "emerging contaminants" in water supplies. These contaminants include human and veterinary drugs, industrial and

Each water-quality problem has its own list of factors that must be understood to construct a scientifically defensible TMDL and one that is likely to alleviate the defined problem.

household wastewater products, and reproductive and steroidal hormones. Although these compounds are not currently considered as TMDL issues, they could be of concern when the risks of low-level exposure are determined for humans and aquatic life.

\section{Information Sharing and Technology Transfer}

The USGS has a long history of information sharing and technology transfer through the Federal - State Cooperative
Program and other USGS programs. In addition, the USGS is helping to increase the sharing of information and technology transfer through the Advisory Committee on Water Information and the National WaterQuality Monitoring Council and through support of meetings such as the Monitoring Council's conferences and the TMDL Science Issues Conference. The USGS co-chairs the National Water-Quality Monitoring Council, whose purposes are to provide national coordination for implementation of the strategy to improve water-quality monitoring in the United States and to develop waterquality information standards through the Methods and Data Comparability Board. As a multidisciplinary, non-regulatory agency, the USGS contributes an objective scientific perspective to TMDL issues. -Allison Shipp and Gail E. Cordy

For more information contact: USGS Office of Water Quality 412 National Center

Reston, VA 20192

(703) 648-6862

http://water.usgs.gov/owq/

\section{Selected References}

Elder, Don, Killam, Gayle, and Koberstein, Paul, 1999, The Clean Water Act: An Owner's Manual: River Network, Portland, OR, p. 157.

Goolsby, D.A., Battaglin, W.A., 2000, Nitrogen in the Mississippi BasinEstimating sources and predicting flux to the Gulf of Mexico, U.S. Geological Survey Fact Sheet FS-135-00.

Smith, R.A., Schwarz, G.E., and Alexander, R.B., 1997, Regional interpretation of water-quality

monitoring data: Water Resources Research, v. 33, p. 2781-2798.

U.S. Environmental Protection Agency, 2000, Atlas of America's polluted waters, EPA 840-B-00-002, May 2000, $53 \mathrm{p}$.

U.S. Geological Survey, 1997-present, National field manual for the collection of water-quality data: Techniques of Water-Resources Investigations, Book 9, Chaps. A1-A9, variously paged.

Woodside, M.D., and Hoos, A.B., 2001,
Nutrients in streams and rivers in the lower Tennessee River Basin: U.S. Geological Survey Fact Sheet FS-025$01,6 \mathrm{p}$.

On the World Wide Web visit: http://water.usgs.gov/owq/tmdl/ http://ks.water.usgs.gov/Kansas/TMDL/ http://water.usgs.gov/nawqa/sparrow/ http://toxics.usgs.gov/ http://water.usgs.gov/usa/nwis http://www.epa.gov/owow/tmdl/ http://water.usgs.gov/owq/FieldManual/ http://www.nap.edu/books/0309075793/html/ 